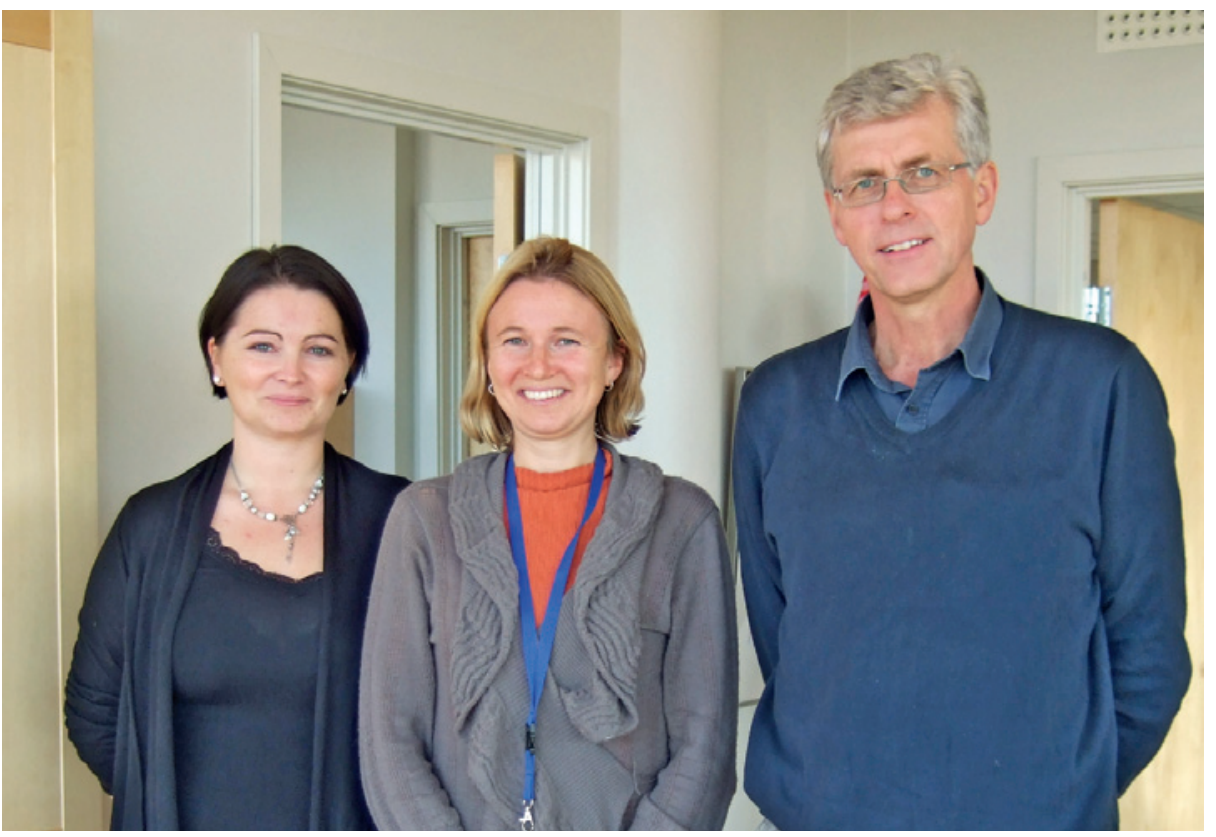

Førsteforfatter Per Magnus og to medforfattere, Gun Peggy Knudsen og Gudrun Høiseth. Foto privat

\title{
Moderat alkoholbruk beskytter mot hjerteinfarkt
}

Moderate mengder alkohol kan ha en beskyttende effekt på utviklingen av hjerteinfarkt, ifølge ny norsk forskning.

Forskerne fulgte ca. 150000 personer fra norske befolkningsundersøkelser (CONOR) gjennom flere år. Disse svarte på spørreskjemaer om sitt alkoholinntak, og målinger av HDL-kolesterolnivå ble foretatt. Dataene ble koblet til Dødsårsaksregisteret (1).

Menn som drakk alkohol én gang i uken eller oftere hadde $45 \%$ lavere risiko for å dø av hjerteinfarkt enn menn som ikke drakk (justert hasardratio $0,55,95 \% \mathrm{KI}$ $0,41-0,73)$. For kvinner var det forskjellen mindre (justert hasardratio 0,68, $95 \% \mathrm{KI}$ $0,34-1,34)$. Denne beskyttende effekten er i samsvar med funn i en lang rekke befolkningsundersøkelser $i$ andre land.

- Vi undersøkte om den risikosenkende effekten var knyttet til endringer i nivået av HDL-kolesterol, sier Gudrun Høiseth, som var en av forskerne bak studien. - Antakelsen var at økt nivå at HDL-kolesterol minsker risikoen for hjerteinfarkt. Tidligere har man trodd at sammenhengen mellom alkohol og hjerte- og karsykdom skyldtes HDL-kolesterol, fordi man på den ene side har vist at alkoholinntak på kort sikt øker konsentrasjonen av HDL-kolesterol i blodet og på den annen side har sett at personer med høyt HDL-kolesterolnivå har lav risiko for hjertesykdom.

Vi fant at reduksjonen i risiko for hjerteinfarkt ikke ble endret når vi korrigerte for nivået av HDL-kolesterol. Dette tyder på at HDL-kolesterolnivået ikke har betydning for sammenhengen mellom alkohol og hjerteinfarkt, slik man har trodd, og at man bør lete etter andre mekanismer for effekten.

Det er viktig å være klar over at gjentatt og stort alkoholinntak øker risikoen for høyt blodtrykk, hjerneslag, enkelte former for kreft og leversykdom, sier Høiseth. - Dessuten er risikoen for skader på indre organer økt.

\section{Forskergruppen}

Artikkelen er skrevet av Per Magnus, Eirin Bakke, Dominic A. Hoff, Gudrun Høiseth, Sidsel Graff-Iversen, Gun Peggy Knudsen, Ronny Myhre, Per Trygve Normann, Øyvind Næss, Kristian Tambs, Dag S.

Thelle og Jørg Mørland ved Folkehelseinstituttet. Forskergruppen ledes av professorene Per Magnus og Jørg Mørland. Gruppen studerer sammenhengen mellom alkohol og hjertesykdom. De har kompetanse innen flere områder. Det videre arbeidet utføres nå på genetiske problemstillinger i et underutvalg av den samme populasjonen.

\section{Erlend Hem}

erlend.hem@medisin.uio.no

Tidsskriftet

\section{Litteratur}

1. Magnus P, Bakke E, Hoff DA et al. Controlling for high-density lipoprotein cholesterol does not affect the magnitude of the relationship between alcohol and coronary heart disease. Circulation 2011; 124: 2296-302.

\section{Ordforklaring}

CONOR (Cohort of Norway) er et samarbeidsprosjekt mellom Folkehelseinstituttet og universitetene i Oslo, Bergen, Trondheim og Troms $\varnothing$. Det omfatter helsedata og blodprøver fra ti regionale helseundersøkelser som ble gjennomført i perioden 1994-2003.

Artikkelen i Circulation omfattet data fra spørreskjemaer, blodprøver og blodtrykksmålinger av 149729 voksne deltakere. De ble fulgt til 2006 via koblinger til Dødsårsaksregisteret.

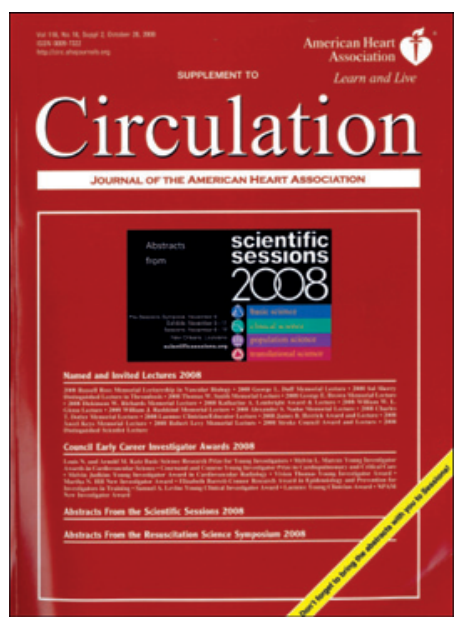

Artikkelen ble e-publisert 31.10. 2011 i det prestisjetunge tidsskriftet Circulation (http://circ.ahajournals.org). 